Jurnal Keperawatan Silampari

Volume 5, Nomor 1, Desember 2021

e-ISSN: 2581-1975

p-ISSN: 2597-7482

DOI: https://doi.org/10.31539/jks.v5i1.3049

IMMEKpe

\title{
HOMOGENISASI SEKUNDER TERHADAP KADAR HEMOGLOBIN
}

\author{
Rosnita Sebayang ${ }^{1}$, Hotman Sinaga ${ }^{2}$, Mustika Sari Hutabarat ${ }^{3}$ \\ Universitas Katolik Musi Charitas ${ }^{1,2,3}$ \\ ros.sebayang@gmail.com ${ }^{1}$
}

\begin{abstract}
ABSTRAK
Penelitian ini bertujuan untuk mengetahui hasil pemeriksaan hemoglobin dengan teknik homogenisasi sekunder 3, 5, 7, dan 8 kali, setelah didiamkan 60 menit pasca homogenisasi primer. Metode penelitian yang digunakan adalah penelitian pre-eksperimental. Hasil penelitian menunjukkan bahwa rata--rata hemoglobin yang diukur dengan alat automatic analyzer hematology pada kelompok darah yang dihomogenisasi sekunder 3 kali 13,3 $\mathrm{g} / \mathrm{dl}$, homogenisasi 5 kali 13,1 g/dl, homogenisasi 7 kali 13,2 g/dl dan homogenisasi 8 kali 13,1g/dl. Simpulan, tidak terdapat perbedaan kadar haemoglobin pada proses homogenisasi sekunder 3, 5, 7 dan 8 kali.
\end{abstract}

Kata Kunci : Darah EDTA, Hemoglobin, Homogenisasi

\begin{abstract}
This study aims to determine the results of hemoglobin examination with secondary homogenization techniques 3, 5, 7, and 8 times, after being left for 60 minutes after primary homogenization. The research method used is pre-experimental research. The results showed that the average hemoglobin measured by an automatic hematology analyzer in the secondary homogenized blood group was 3 times $13.3 \mathrm{~g} / \mathrm{dl}$, homogenized 5 times $13.1 \mathrm{~g} / \mathrm{dl}$, homogenized 7 times $13.2 \mathrm{~g} / \mathrm{dl}$, and homogenization 8 times $13.1 \mathrm{~g} / \mathrm{dl}$. In conclusion, there is no difference in hemoglobin levels in the secondary homogenization process 3, 5, 7, and 8 times.
\end{abstract}

Keywords: EDTA Blood, Hemoglobin, Homogenization

\section{PENDAHULUAN}

Pemeriksaan hematologi adalah suatu kegiatan pelayanan kesehatan dibidang laboratorium yang meliputi pemeriksaan sitologi sel darah, sitokimia darah, analisa hemoglobin, analisa darah rutin, bank darah, hemolisa dan kelompok pemeriksaan lain. Hemoglobin merupakan protein yang dapat mengikat zat besi sebagai komponen utama sel darah merah yag mempunyai fungsi mentranportasi oksigen dan carbon dioksida, sehingga dapat menyebabkan warna pada eritrosit (Kure \& Sakai, 2021).

Anemia adalah kondisi tubuh seseorang yang mengalami penurunan terhadap sel darah merah, kadar hemoglobin dan kadar hematokrit (Mustika et al., 2019). Pada pemeriksaan hemoglobin di laboratorium harus menggunakan sampel darah vena, darah yang berada di luar tubuh cepat membeku, oleh sebab itu harus dengan penambahan antikoagulan EDTA dengan tujuan untuk menghambat dan mencegah proses pembentukan bekuan darah. Darah yang ditampung dalam tabung EDTA perlu dilakukan homogenisasi guna mencampur sampel darah dengan antikoagulan. Homogenisasi 
dilakukan dengan cara membolak balikkan tabung sampel 8 - 10 kali terhadap darah yang baru dimasukkan kedalam tabung berisi antukoagulan EDTA dalam perlakuan homogenisasi primer (Simundic et al., 2020).

Menurut data World Health Organization (WHO) lebih dari $30 \%$ atau 2 milyar orang di dunia berstatus anemia, prevalensi animia di Indonesia mencapai 21,7 \% dan 18,4 \% penderita berusia 15 - 25 tahun. Berdasarkan data Riskesdas tahun 2018 di Indonesia sebesar 48,9 \% ibu hamil mengalami anemia (Mustika et al., 2019).

Darah yang telah dihomogenisasi primer biasanya tidak langsung diperiksa tetapi didiamkan dahulu. Penundaan pemeriksaan sering terjadi karena beberapa faktor, seperti pengiriman dari bangsal yang tidak segera dilakukan atau petugas laboratorium dalam melakukan pengambilan sampel darah tidak segera diperiksa dikarenakan pasien yang mau diambil darahnya terlalu banyak (Hartina et al., 2019). Darah dengan antikoagualan yang dibiarkan dalam waktu tertentu akan mengalami pemisahan menjadi dua lapisan atas berupa plasma, sedangkan lapisan bawah berupa sel darah (Rosidah \& Wibowo, 2018)

Bila darah dengan antikoagulan yang didiamkan harus dilakukan homogenisasi jika akan diperiksa karena sel-sel telah mengendap saat didiamkan, maka perlu dilakukan homogenisasi sekunder. Pada saat sel-sel darah sudah mengendap dan jika dilakukan pemeriksaan tanpa melakukan homogenisasi maka hasilnya menjadi kurang akurat, di karenakan jika darah dan antikoagulan tidak dilakukan pencampuran dengan baik maka menyebabkan bekuan yang memberikan hasil rendah palsu, sedangkan jika pencampuran dilakukan berlebihan akan menyebabkan hemolisis. Oleh karena itu homogenisasi harus dilakukan dengan baik agar darah terdistribusi normal (Lestari, 2019).

Pada darah yang terdapat antikoagulant dan telah dilakukan homogenisasi primer, jika darah didiamkan maka sel-sel darah akan mengalami pengendapan. Proses pengendapan melalui 3 tahap yaitu tahap pertama pembentukan rouleaux dimana sel eritrosit akan mengalami agregasi dan membentuk tumpukan dengan kecepatan pengendapan darah lambat yang berlangsung selama 10 menit. Tahap kedua yaitu proses sedimentasi dimana eritrosit mengalami pengendapan lebih cepat dan konstan berlangsung selama 40 menit. Tahap ketiga adalah tahap pemadatan yaitu eritrosit yang mengendap mengisi celah atau ruang kosong pada tumpukan darah yang berlangsung selama 10 menit dengan kecepatan lambat (Alshaghdali et al., 2021). Sebelum darah pada tabung EDTA dimasukkan ke alat maka perlu dilakukan homogenisasi sekunder. Proses homogenisasi sekunder dilaboratorium ada yang menggunakan mixer rotator dan ada yang menggunakan teknik pencampuran bolak balik atau inversi. Belum ada secara standar berapa kali perlakuan homogenisasi sekunder ini harus dilakukan, supaya darah yang bercampur dengan antikoagulan EDTA benar-benar terdistribusi normal untuk dibaca pada alat untuk pemeriksaan sel-sel darah (Kure \& Sakai, 2021).

Menurut Permenkes RI No 43 tahun 2013, pemeriksaan hemoglobin dibagi dalam tahapan pra analitik, analitik dan pasca analitik. Setiap tahapan yang dilakukan untuk pemeriksaan harus dilakukan dengan baik dan sesuai dengan prosedur yang sudah ditetapkan. Pada pemeriksaan ini kesalahan dapat terjadi, pada setiap tahap kegiatan yang dilakukan dengan benar sesuai prosedur. Potensi kesalahan pada setiap tahap berbedabeda. Pada tahap pra analitik kesalahan dapat mencapai 46-61\%, tahap analitik kesalahan dapat mencapai $7-25 \%$ dan besaran kesalahan untuk tahap pasca analitik sebesar 1447\% (Aipassa et al., 2020).

Hasil pemeriksaan laboratorium yang tepat dan dapat dipercaya merupakan penunjang yang mutlak diperlukan dalam pengelolaan suatu penyakit. Sayangnya, masih dijumpai ketidaksesuaian antara hasil pemeriksaan laboratorium dengan keadaan klinis 
pasien. Hal ini dapat diakibatkan pemeriksaan laboratorium yang dilakukan tidak sesuai prosedur. Pengambilan dan pemerosesan yang tepat terhadap spesimen darah merupakan langkah awal tahap preanalitik yang sangat penting karena turut menentukan keakuratan pengukuran dan hasil yang dapat dipercaya dari pemeriksaan laboratorium klinik. Jumlah pemberian antikoagulan yang beragam dapat juga terjadi yang dapat menyebabkan kesalahan hasil pemeriksaan (Alshaghdali et al., 2021).

Homogenisasi primer secara teknis sudah ditetapkan oleh lembaga seperti CLSI (Clinical and Laboratory Standard Institute) 2017, (BD vacuteiner Order of Draw, Note : always follow, 2002) dan Permenkes No 43 tahun 2013. CLSI menyatakan bahwa homogenisasi primer yang dapat dilakukan adalah sebanyak $8-10$ kali dibolak-balik. BD vacutainer menyatakan bahwa homogenisasi primer dapat dilakukan sebanyak $8-10$ kali dibolak-balik beda dengan Permenkes menyatakan bahwa homogenisasi primer sampel dilakukan 10 -12 kali dibolak - balik. Sedangkan homogenisasi sekunder yang merupakan homogenisasi sampel dapat dilakukan ketika akan melakukan pemeriksaan ke alat sysmex KX 21. Beberapa literatur dan jurnal yang telah diperoleh belum terdapat rekomendasi atau aturan tentang homogenisasi sekunder (Ramadhani et al., 2019).

Penelitian sebelumnya menyebutkan bahwa teknik homogenisasi sekunder yang digunakan adalah dengan mixer tipe rotator coulter LH 780, dimana pada penelitian ini membandingkan antara homogenisasi yang dilakukan dengan cara langsung diperiksa $(\mathrm{t}=$ $0)$, menggunakan rotator $\mathrm{t} 1$ menit $(\mathrm{t}=1)$ dan 5 menit $(\mathrm{t}=5$ menit $)$. Dimana hasil yang didapatkan pada penelitian tersebut adalah terdapat perbedaan yang significan terhadap kadar neutrofil, monosit, red blood cell (eritrosit) dan Mean Platelet Volume ( MVP ) yang langsung diperiksa $(\mathrm{t}=0)$ dengan darah yang sudah dihomogenisasi dengan rotator selama 5 menit $\mathrm{t}=5$ (Yucel et al., 2017).

Simundic et al., (2020) hemoglobin yang diperiksa secara prosedur in vitro atau yang dilakukan secara di luar organisme hidup. Pelaksanaan dilakukan di dalam tabung EDTA dimana secara khusus sudah ditentukan konsentrasi dan jumlah volume darah yang dalam pengambilan dilakukan secara vacum. Hal ini juga masih sering terjadi hemolisis yang mengakibatkan gangguan pada sel-sel darah, sehingga hasil pemeriksaan juga menjadi terganggu.

Zat yang ditambahkan kedalam darah yang bertujuan untuk menghambat atau mencegah proses bekuan darah dengan cara mengikat atau mengendapkan ion kalsium dan menghambat pembentukan trombin dan protrombin. Adapun antikoagulan yang sering dipakai untuk pemeriksaan darah rutin adalah EDTA. Dengan pemberian antikoagulan EDTA maka akan didapat sampel darah untuk keperluan pemeriksaan selsel darah, yang memiliki pengaruh yang berbeda terhadap sel yang lain dan penambahannya sesuai dengan volume darah pada tabung vacum (Alshaghdali et al., 2021).

Sehubungan dengan homogenisasi sekunder yang belum dilakukan pada beberapa penelitian tersebut dan berdasarkan pengamatan dilapangan terhadap frekuensi dan cara yang tidak sama dalam melakukan homogenisasi sekunder yaitu dengan cara inversi dan angka delapan serta dengan jumlah homogenisasi yang dilakukan bervariasi. Maka hal tersebut yang mendasari penulis dalam melakukan penelitian untuk mengetahui hasil pemeriksaan hemoglobin yang diperoleh dari perlakuan homogenisasi sekunder 3, 5, 7 dan 8 kali. Karena belum adanya standar pada pelaksanaan homogenisasi sekunder, maka dibuat sebagai perbandingan adalah 8 kali dengan teknik inversi homogenisasi sekunder. Banyak penelitian hanya berfokus pada homogenisasi primer. 


\section{METODE PENELITIAN}

Jenis penelitian yang digunakan adalah penelitian pre-eksperimental. Penelitian ini dilakukan untuk melihat pengaruh homogenisasi terhadap kadar hemoglobin menggunakan darah EDTA, yang dilakukan homogenisasi sekunder 3, 5, 7 dan 8 kali. Karena belum ada standar untuk perlakuan homogenisasi sekunder, yang dilakukan ketika akan dilakukan pemeriksaan baik secara manual ataupun automatic.

Subjek penelitian adalah 32 mahasiswa DIV Teknologi Laboratorium Medis Fakultas Ilmu Kesehatan UKMC yang memenuhi kriteria inklusi dan eksklusi kemudian diambil darah sebanyak 2 CC. Kemudian darah ditampung dalam 4 tabung bertutup ungu (tabung EDTA) yang masing- masing tabung pertama, kedua, ketiga dan keempat sudah diberi kode, dihomogenisasi inversi primer 8 kali, didiamkan 60 menit lalu dilakukan homogenisasi sekunder dengan teknik inversi 3, 5, 7 dan 8 kali dan dilanjutkan pembacaan pada alat sysmex $K X 21$, lalu dilakukan pembacaan parameter hemoglobin. Pemeriksaan dilakukan di laboratorium Fikes UKMC, Jln Suka Bangun II Palembang.

Metode pengambilan sampel adalah total sampling. Sampel yang digunakan adalah mahasiswa DIV Analis Kesehatan Fakultas Ilmu Kesehatan UKMC. Data hasil penelitian di uji dengan uji statistik one way anova.

\section{HASIL PENELITIAN}

\section{Hasil Verfikasi Metode Pemeriksaan Hemoglobin}

Tabel. 1

Hasil Verifikasi Metode Sysmex KX 21,

Pemeriksaan Hemoglobin

\begin{tabular}{ccccc}
\hline & $\begin{array}{c}\text { Bahan } \\
\text { Kontrol }\end{array}$ & Hasil & $\begin{array}{c}\text { Batas } \\
\text { Keberterimaan }\end{array}$ & Keterangan \\
\hline Presisi/CV & Low & $1,3 \%$ & $1,5 \%$ & Diterima \\
& Normal & $1.1 \%$ & & \\
& High & $0,1 \%$ & $1,84 \%$ & Diterima \\
\hline Akurasi/Bias & Low & $1,4 \%$ & & \\
& Normal & $0,0 \%$ & & Diterima \\
& High & $0,81 \%$ & $11,4 \%$ & \\
\hline
\end{tabular}

Berdasarkan tabel 1 menunjukan bahwa presisi metode sysmex KX 21, pemeriksaan hemoglobin dari bahan control low sebesar 1,3\%, bahan kontrol normal sebesar 1,1\%, dan high sebesar 0,1\% dan untuk akurasi bahan control low sebesar 1,4\%, normal sebesar $0,0 \%$ dan high sebesar $0,81 \%$ serta TEa low sebesar 4,0 \%, normal 4,21\% dan high sebesar 5.61\%. Hasil uji presisi, akurasi dan TEa dapat diterima.

Untuk pemantapan mutu internal, dilakukan pemeriksaan terhadap bahan control, yang dilaksanakan pada 2 periode, dimana periode control dengan memeriksa 25 kali dalam sehari, diperoleh nilai rata-rata hemoglobin 13,8 g/dl dan standard deviasi 0,13. Nilai ini dipakai untuk periode control, yang dipakai sebagai nilai rujukan, sebelum kepemeriksaan. 


\section{Karakteristik Subjek Penelitian}

Tabel. 2

Distribusi Subjek Penelitian

Berdasarkan Umur

\begin{tabular}{ccc}
\hline Umur & Frekuensi $(\mathrm{n}=32)$ & Presentae $\%$ \\
\hline $19-20$ tahun & 2 & $6.25 \%$ \\
$20-21$ tahun & 12 & $37.5 \%$ \\
$21-22$ tahun & 4 & $12.5 \%$ \\
$22-23$ tahun & 12 & $37.5 \%$ \\
$23-24$ tahun & 2 & $6.25 \%$ \\
\hline Jumlah & 32 & $100 \%$ \\
\hline
\end{tabular}

Berdasarkan tabel 2 diketahui bahwa kebanyakan umur yang menjadi subjek penelitian adalah umur 20 tahun dengan jumlah 12 orang dengan persentase sebesar $37.5 \%$.

\section{Hasil Pemeriksaan Kadar Hemoglobin}

Tabel. 3

Hasil Pemeriksaan Kadar Hemoglobin dalam Darah EDTA

\begin{tabular}{lccc}
\hline \multicolumn{1}{c}{ Variabel } & $\begin{array}{c}\text { Mean/Kadar Rata- } \\
\text { rata }\end{array}$ & SD & p value \\
\hline $\begin{array}{l}\text { Homogenisasi sekunder } \\
\text { Inversi 3 kali }\end{array}$ & 13,3 & 1,43 & \\
\hline $\begin{array}{l}\text { Homogenisasi sekunder } \\
\text { Inversi 5 kali }\end{array}$ & 13,1 & 1,41 & $\mathrm{p}=0,938$ \\
\hline $\begin{array}{l}\text { Homogenisasi sekunder } \\
\text { Inversi 7 kali }\end{array}$ & 13,2 & 1,45 & \\
\hline $\begin{array}{l}\text { Homogenisasi sekunder } \\
\text { Inversi 8 kali }\end{array}$ & 13,1 & 1,44 & \\
\hline
\end{tabular}

Berdasarkan tabel 3 diketahui bahwa hasil rata-rata pengukuran kadar hemoglobin darah EDTA yang dihomogenisasi $3 \mathrm{kali}=13,3 \mathrm{~g} / \mathrm{dl}$, rata-rata pengukuran hemoglobin 5 kali dihomogenisasi sebesar 13,1 g/dl, rata-rata pengukuran kadar hemoglobin 7 kali sebesar 13,2 g/dl dan rata-rata pengukuran hemoglobin 8 kali di homogenisasi sebesar $13,1 \mathrm{~g} / \mathrm{dl}$. Hasil pengukuran ini kemudian diuji secara statistik menggunakan uji one way anova, diperoleh nilai p: 0,938 (>0,05), artinya tidak ada perbedaan antara kadar hemoglobin dalam darah EDTA yang dihomogenisasi 3, 5, 7, dan 8 kali.

\section{PEMBAHASAN}

Sebelum dilakukan penelitian, metode dan alat terlebih dahulu telah dilakukan verifikasi dan pemantapan mutu internal. Hal ini untuk memastikan kehandalan metode pemeriksaan yang digunakan dalam penelitian. Selain dilakukan verifikasi metode, faktorfaktor yang memungkinkan terjadinya kesalahan atau gangguan saat pemeriksaan juga dihitung. Faktor-faktor yang memungkinkan terjadinya kesalahan atau eror dalam pemeriksaan dinyatakan sebagai nilai keberterimaan total eror (Allowable Total Error: $T E a)$. TEa dihitung dengan menjumlahkan persentase bias dengan dua kali persentase 
$\mathrm{CV}$. Batas nilai TEa ditentukan sebagai ukuran suatu metode bisa digunakan, selain menghitung presisi dan akurasi. CLIA (Clinical Laboratory Improvement Amendments) menuliskan batas TEa untuk metode pemeriksaan hemoglobin adalah $<11,4 \%$. Nilai TEa yang diperoleh pada penelitian ini sebesar 4,0 \% untuk kontrol low, 4,21\% untuk kontrol normal dan 5,61\% untuk kontrol high. Hasil tersebut tidak melebihi TEa yang diperbolehkan. Hal ini membuktikan bahwa metode pemeriksaan hemoglobin yang digunakan dalam penelitian ini memang benar-benar layak digunakan (Alshaghdali et al., 2021).

Periode pendahuluan dilakukan pada tanggal 30 Juni 2021 untuk pemeriksaan hemoglobin dengan mengukur bahan kontrol normal (no. batch: 11140822, tanggal kadaluarsa: 31 Juli 2021). Pada periode pendahuluan ini dilakukan pemeriksaan bahan kontrol 25 kali secara bertutut-turut. Hasil kemudian dicatat dan dihitung nilai rataratanya (mean) dan nilai Standar Deviasi (SD). Hasil pemeriksaan bahan kontrol normal diperoleh mean 13,8 g/dL dan SD 0,13. Nilai mean dan nilai SD ini dipakai sebagai nilai rujukan pada periode berikutnya yaitu periode control dan untuk membuat grafik levey jenning churt yang akan digunakan untuk periode control. Pemeriksaan bahan control pada periode control dilakukan sebelum sampel pasien diperiksa. Bahan control yang diperiksa pada tanggal 2 juli 2021 untuk pemeriksaan hemoglobin dengan mengukur bahan control normal, hasil pemeriksaan bahan control normal adalah 13,8 mg/dl dan diperoleh $\mathrm{S}$ dalam satuan standar deviasi 0,76, kemudian di plotkan pada grafik levey jenning churt dan diinterpretasikan menggunakan aturan Westgard Multirules. Hasil bahan control yang diplotkan menurut aturan.

Berdasarkan hasil penelitian yang diperoleh dapat dilihat bahwa tidak terdapat perbedaan hasil pengukuran kadar hemoglobin pada sampel yang dihomogenisasi inversi sekunder sebanyak 3, 5, 7 dan 8 kali. Hal ini sejalan dengan penelitian Yusel dkk yang menyebutkan bahwa tidak terdapat perbedaan hasil pemeriksaan kadar hematokrit, dan eritrosit pada tabung yang diperiksa dengan tidak melakukan homogenisasi sekunder inversi, tetapi untuk homogenisasi menggunakan alat, dengan tabung -tabung yang dibiarkan 5 menit, kemudian sebelum masuk ke alat sismex KX21, dihomogenkan dengan teknik mixer rotator beckman coulter LH 780 selama 1 menit dan 5 menit. Hasil Penelitian Hartina dkk, dalam penelitian ini membedakan teknik homogenisasi primer dengan teknik homogenisasi angka delapan dan teknik inversi, didapatkan hasil ada perbedaan kadar trombosit, pada penelitian ini tidak dibahas mengenai homogenisasi sekunder. Hal ini sejalan dengan penelitian yang telah dilakukan oleh (Sari \& Darmadi, 2018) menunjukkan bahwa hasil penelitian tidak terdapat perbedaan yang signifikan pada pemeriksaan sel darah lekosit setelah dilakukan penundaan pemeriksaan selama 2 jam, akan tetapi pada penelitian ini tidak ada penjelasan berapa kali dilakukan homogenisasi sekunder sebelum darah EDTA, dimasukkan ke alat pemeriksaan sel darah lekosit.

Menurut penelitian Sari \& Darmadi (2018) didapatkan hasil penelititan yang dilakukan dan hasil yang didapatkan mengenai perbandingan jumlah leukosit darah EDTA segera diperiksa dan ditunda 2 jam, tidak terdapat perbedaan bermakna dengan $p$ value $=0,662$, dan semua hasil dalam batas normal.

Utami et al., (2019) dalam penelitiannya yang menggunakan 30 sampel dengan perlakuan membedakan pemakaian 2 tabung, dimana 1 tabung menggunakan $\mathrm{K}_{2}$ EDTA dengan tabung menggunakan antikoagulan $\mathrm{K}_{3}$ EDTA, setelah dilakukan homogenisasi primer 8 kali. Tabung kedua dan dan ketiga dan keempat dibiarkan selama 2, 4, 6, dan 8 jam, baru diperiksa pada alat. Hasil penelitian menunjukkan menunjukkan tidak ada perbedaan yang signifikan antara pemeriksaan hemoglobin yang dilakukan pada kedua 
jenis antikoagulan tersebut, walaupun pada penelitian tidak disebutkan berapa kali dilakukan homogenisasi sekunder.

Pada pelaksanaan pra analitik, hasil pemeriksaan laboratorium klinik sangat berpengaruh terhadap kompleknya pelaksanaan homogenisasi, dimana diantaranya hasil menjadi lebih rendah dari sebenarnya, dan sebaliknya apabila homogenisasi terlalu berlebihan bisa menyebabkan sampel darah menjadi lisis yang ditandai dengan pecahnya sel darah merah yang terlihat pada plasma, sebelum dilakukan pemeriksaan ke alat pemeriksaan sel-sel darah (Gupta et al., 2021).

Pemeriksaan yang menggunakan darah EDTA, sebaiknya harus dilakukan dengan segera, bila terpaksa ditunda sebaiknya harus diperhatikan batas waktu penyimpanan untuk masing - masing pemeriksaan. Penyimpanan darah EDTA pada suhu kamar yang terlalu lama dapat menyebabkan terjadinya serangkaian perubahan pada eritrosit seperti pecahnya membran eritrosit (hemolisis) sehingga hemoglobin bebas ke dalam medium sekelilingnya plasma (Ramadhani et al., 2019).

Kure \& Sakai (2021) pemeriksaan laboratorium pada umumnya melewati 3 tahap yaitu pra instrumentasi, instrumentasi dan pasca instrumentasi. Tahap pra instrumentasi meliputi persiapan pasien, pengambilan, penampungan, penyimpanan dan pengiriman bahan. Hasil pemeriksaan laboratorium khususnya hematologi banyak diminta para dokter untuk menegakkan diagnosis, menunjang diagnosis, membuat diagnosis banding, memantau perjalanan penyakit, menilai beratnya sakit dan menentukan prognosis. Pemeriksaan laboratorium yang telah melalui ketiga tahap pemeriksaan harus dilakukan menurut prosedur yang telah ada, sehingga didapatkan hasil yang teliti, tepat, cepat dan dapat dipercaya. Pemeriksaan hematologi meliputi parameter kadar hemoglobin, hitung lekosit, eritrosit, trombosit, hematokrit, hitung retikulosit, laju endap darah dan pemeriksaan khusus lainnya.

Darah utuh atau whole blood specimen darah yang memiliki komponen darah secara utuh dan kondisinya sama dengan di dalam aliran darah dalam tubuh. Specimen darah utuh didapatkan dengan penambahan antikoagulan untuk menghambat pembekuan darah. Penambahan antikoagulan harus disesuaikan dengan jenis pemeriksaan (Lestari, 2019). Specimen darah utuh yang didiamkan terlalu lama akan mengalami pengendapan sel-sel darah sehingga akan terjadi pemisahan antara sel darah dan plasma, sehingga perlu dilakukan pencampuran kembali agar komponen darah homogeny sebelum pemeriksaan (Rosidah \& Wibowo, 2018).

Banyak sekali faktor yang mempengaruhi hasil dari pemeriksaan sel darah, pada proses homogenisasi, bisa menyebabkan keberadaan sel berbeda satu sama lain, ada yang berada di bawah, adalagi sel yang berada di atas lapisan darah dan ada juga yang menempel pada tepian tabung EDTA. Tetapi ditinjau dari sisi massa jenis kebanyakan sel- sel darah berada di bawah. Oleh sebab itu maka sangat perlu untuk melakukan homogenisasi sekunder. Apalagi kalau darah EDTA sudah ada penundaan selang waktu beberapa jam (Kure \& Sakai, 2021).

Untuk pemeriksaan hemoglobin menggunakan darah vena, yang dimasukkan dalam tabung yang sudah beriisi antikoagulan untuk menghindari pembekuan. Antikoagulan yang biasa dipakai untuk pemeriksaan hematologi adalah EDTA (Ethylene Diamine Tetra Asetic Acid).

Pada pemerosesan yang tepat terhadap specimen darah EDTA, merupakan langkah awal tahap pre analitik yang sangat penting karena turut menentukan keakuratan pengukuran dan hasil dapat dipercaya dari pemeriksaan laboratorium klinik. Jumlah pemberian antikoagulan yang beragam dapat juga terjadi dan dapat menyebabkan 
kesalahan pemeriksaan.

Pemeriksaan yang menggunakan darah EDTA, sebaiknya harus dilakukan dengan segera, bila terpaksa ditunda sebaiknya harus diperhatikan batas waktu penyimpanan untuk masing-masing pemeriksaan sel darah. Penyimpanan darah EDTA yang terlalu lama pada suhu kamar dapat menyebabkan perubahan pada eritrosit seperti pecahnya membran eritrosit menyebabkan terjadinya hemolysis sehingga hemoglobin bebas kedalam medium sekelilingnya. Perlunya memperhatikan teknik homogenisasi sekunder.

Terutama pada darah EDTA, disini perlakuan kedua setelah darah diambil dari vena cubiti darah ditampung dalam 4 tabung, kemudian dihomogenisasi primer secara inversi (bolak-balik), 8 kali, kemudian darah dalam tabung dibiarkan 60 menit, baru dihomogenkan sekunder, dibuat pada tabung A 3 kali, tabung ke B 5 kali, tabung C 7 kali, dan tabung D 8 kali sebagai standar yang untuk sementara disamakan dengan homogenisasi primer menurut Permenkes dan BD Vacuitainer. Belum adanya standar yang menyatakan berapa kali dilakukan homogenisasi sekunder, sebelum tabung EDTA masuk ke alat pemeriksaan. Sehubungan dengan perlakuan homogenisasi sekunder yang belum diteliti berapa kali sebenarnya harus dilakukan, mengapa dilakukan penundaan selama 60 menit setelah homogenisasi primer. Darah dengan antikoagulan dalam tabung EDTA dibiarkan akan mengalami pemisahan sehingga menjadi 2 lapisan, lapisan atas berupa plasma dan lapisan bawah berupa sel-sel darah. Pemisahan tersebut ditentukan oleh massa jenis sel eritrosit yang dipengaruhi oleh komposisi plasma. Proses pengendapan darah tersebut terjadi dalam 3 tahap. Tahap pertama pembentukan reuleaux, sel-sel eritrosit akan mengalami agregasi dan membentuk tumpukan dengan kecepatan pengendapan dalam waktu 10 menit. Tahap kedua proses sedimentasi, eritrosit akan mengalami pengendapan lebih cepat dan konstan yang berlangsung selama 40 menit. Tahap ketiga adalah tahap pemadatan, eritrosit yang mengendap akan mengisi celah-celah atau ruang kosong pada tumpukan eritrosit lain dibawah tabung, hingga eritrosit benarbenar memadat terakumulasi, tahap ini berlangsung selama 10 menit. Jadi diperhitungkan waktunya selama 60 menit (Simundic et al., 2020).

Penelitian untuk menentukan berapa kali dilakukan homogenisasi sekunder, belum pernah sama sekali, oleh sebab itu belum ada jurnal yang terkait dalam hal ini akan tetapi, berdasarkan fakta dilapangan sering terjadi penundaan setelah dilakukan homogenisasi primer maka penelitian ini langsung mencoba dengan homogenisasi sekunder setelah darah didiamkan pada suhu kamar selama 60 menit (1 jam). Setelah itu maka dilakukan homogenisasi 3, 5, 7 dan 8 kali sebagai gold standard dari perlakuan homogenisasi primer.

\section{SIMPULAN}

Tidak terdapat perbedaan kadar hemoglobin dalam darah yang dihomogenisasi inversi sekunder $3,5,7$, dan 8 kali .

\section{SARAN}

Disarankan untuk melakukan homogenisasi inversi sekunder cukup 3 kali pada pemeriksaan hemoglobin. 


\section{DAFTAR PUSTAKA}

Aipassa, I., Rahayu, M., \& Ariyadi, T. (2020). Perbedaan Kadar Ureum Serum dan Plasma Lithium Heparin. Jurnal Labora Medika, 4, 42-46. https://jurnal.unimus.ac.id/index.php/JLabMed/article/view/7220

Alshaghdali, K., Alcantara, T. Y., Rezgui, R., Cruz, C. P., Alshammary, M. H., Almotairi, Y. A., \& Alcantara, J. C. (2021). Detecting Preanalytical Errors Using Quality Indicators in a Hematology Laboratory. Quality Management in Health Care, 1-8. https://doi.org/10.1097/QMH.0000000000000343

Gupta, P., Thomas, M., Sbetan, N., Chacko, G., Savarimuthu, I., Cherian, P., Abas, A., Shiju, S., Karim, S., Kanaan, A., Bautista, G., Elsalasiny, N., Balushi, S. A., Haga, A. E., \& Hassan, M. E. (2021). A Quality Improvement Initiative to Reduce Rejected Laboratory Samples and Enhance Specimen Acceptability. Joint Commission Journal on Quality and Patient Safety, 47(8), 519-525. https://doi.org/10.1016/j.jcjq.2021.04.005

Hartina, H., Garini, A., \& Tarmizi, M. I. (2019). Perbandingan Teknik Homogenisasi Darah EDTA dengan Teknik Inversi dan Teknik Angka Delapan terhadap Jumlah Trombosit. JPP (Jurnal Kesehatan Poltekkes Palembang), 13(2), 150-153. https://doi.org/10.36086/jpp.v13i2.239

Kure, T., \& Sakai, H. (2021). Preparation of Artificial Red Blood Cells (Hemoglobin Vesicles) Using the Rotation-Revolution Mixer for High Encapsulation Efficiency. ACS Biomaterials Science and Engineering, 7(6), 2835-2844. https://doi.org/10.1021/acsbiomaterials.1c00424

Lestari, A. I. (2019). Different Amount of Thrombocytes on Blood Storage for 24 Hours in Room and Refrigerator. Journal of Vocational Health Studies, 3(2), 59. https://doi.org/10.20473/jvhs.v3.i2.2019.59-62

Mustika, I., Hidayati L, S., Kusumawati, E., \& Lusiana, N. (2019). Anemia Defisiensi Besi dan Indeks Massa Tubuh terhadap Siklus Menstruasi Remaja Putri. Jurnal Kesehatan, 12(1), 30-40. https://doi.org/10.24252/kesehatan.v12i1.7157

Ramadhani, Q. A. N., Garini, A., Nurhayati, N., \& Harianja, S. H. (2019). Perbedaan Kadar Glukosa Darah Sewaktu Menggunakan Serum dan Plasma Edta. JPP (Jurnal Kesehatan Poltekkes Palembang), 14(2), 80-84. https://doi.org/10.36086/jpp.v14i2.407

Rosidah, R., \& Wibowo, C. (2018). Perbedaan antara Pemeriksaan Antikoagulan EDTA dan Heparin terhadap Nilai Hematokrit (HCT). Jurnal Sains, 8(16), 16-21. http://journal.unigres.ac.id/index.php/Sains/article/view/800/671

Sari, D. P., \& Darmadi, D. (2018). Perbedaan Jumlah Leukosit Darah Edta Diperiksa Segera dan Ditunda 2 Jam. Klinikal Sains: Jurnal Analis Kesehatan, 6(2), 30-36. http://jurnal.univrab.ac.id/index.php/klinikal/article/view/578

Simundic, A. M., Baird, G., Cadamuro, J., Costelloe, S. J., \& Lippi, G. (2020). Managing Hemolyzed Samples in Clinical Laboratories. Critical Reviews in Clinical Laboratory Sciences, 57(1), 1-21. https://doi.org/10.1080/10408363.2019.1664391

Utami, A. P., Nurhayati, B., Noviar, G., \& Durachim, A. (2019). Waktu Simpan Darah Antikoagulan K2EDTA dan K3EDTA terhadap Parameter Eritrosit. AIJ Journal of Technology and Design, 11(2), 178-189. https://doi.org/DOI: https://doi.org/10.34011/juriskesbdg.v11i2.743

Yucel, C., Turhan, T., \& Calci, E. (2017). The Effect of Preanalytical Mechanical Mixing Time on Complete Blood Cell Count Parameters in the Emergency Laboratory. Medicine Science|International Medical Journal, https://doi.org/10.5455/medscience.2016.05.8552 